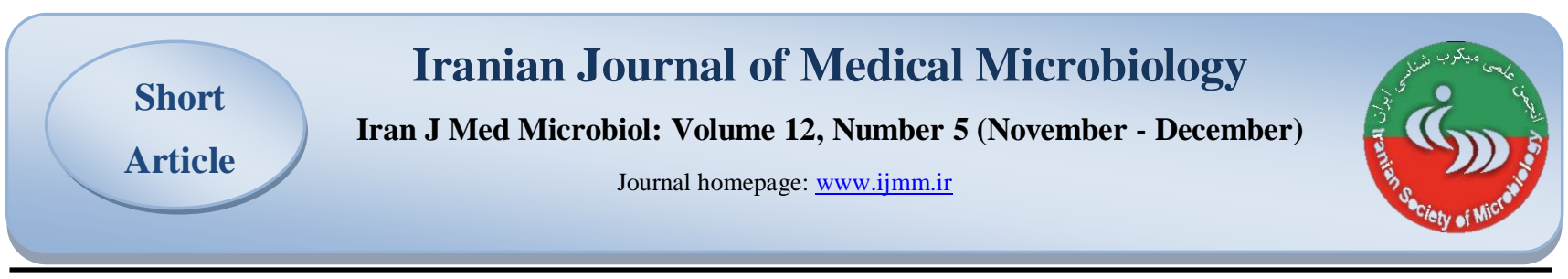

\title{
Seroprevalence of Varicella-Zoster Virus IgG Among Students of Babol University of Medical Sciences: Importance of Vaccine Strategy for Women of Reproductive Age (2016-2017)
}

\author{
Faezeh Rasti Ghamsari1, Farzin Sadeghi2, Mona Moradi' ${ }^{1}$ Marjan Nouri Gorji1, \\ Mahmoud Hajia-Ahmadi ${ }^{3}$, Yousef Yahyapour $^{4} *$ \\ 1. Babol University of Medical Sciences, Babol, Iran \\ 2. Cellular and Molecular Biology Research Center, Health Research Institute, Babol University of Medical Sciences, Babol, Iran \\ 3. Department of Biostatistics, Faculty of Medicine, Babol University of Medical Sciences, Babol, Iran. \\ 4. Infectious Diseases and Tropical Medicine Research Center, Health Research Institute, Babol University of Medical Sciences,
} Babol, Iran

\section{Article Information}

\section{Article history:}

Received: 2018/03/25

Accepted: 2018/12/10

Available online: 2018/12/22

\section{Article Subject:}

Medical Virology

IJMM 2018; 12(5): 357-362

Corresponding author:

\section{Yousef Yahyapour}

Associated Professor in Virology, Infectious Diseases and Tropical Medicine Research Center, Health Research Institute, Babol University of Medical Sciences, Babol, Iran

Email:

uyahyapoor@yahoo.com

Use your device to scan and read the article online

\section{Abstract}

Background and Aims: Chickenpox is a highly contagious disease caused by infection with Varicella Zoster Virus (VZV). Although it is usually a self-limited disease, but severe complications may occasionally occur. The aim of this study was to investigate the seroprevalence of VZV antibody among students of Babol University of Medical Sciences especially female students in reproductive age.

Materials and Methods: 270 students were enrolled to our study. After signing a written informed consent, demographic data and $5 \mathrm{ml}$ blood sample were collected from each participant. Following serum isolation, each serum sample was assessed by ELISA technique for VZV IgG.

Results and Conclusion: Of two hundred and seventy students, 197 were female and 73 were male. Out of female students, 145 students $(73.6 \%)$ were single and in reproductive age. $17.3 \%$ of female students and $8.2 \%$ of male students were seronegative and susceptible to VZV infection. Besides, $7.9 \%$ of unmarried male students and $20.7 \%$ of unmarried female students were susceptible to VZV infection. The highest susceptibility to VZV was seen in 18-21 years age group. Therefore, more than $20 \%$ of unmarried female students were susceptible to VZV, which can be important regarding infection during pregnancy and subsequent severe complications. Consequently, vaccination for VZV in susceptible students especially unmarried female students is recommended.

Keywords: Chickenpox, Varicella Zoster Virus, VZV IgG, Vaccination

Copyright @ 2018 Iranian Journal of Medical Microbiology. All rights reserved.

How to cite this article:

Rasti Ghamsari F, Sadeghi F, Moradi M, Nouri Gorji M, Hajia-Ahmadi M, Yahyapour Y. Seroprevalence of Varicella-Zoster Virus IgG Among Students of Babol University of Medical Sciences: Importance of Vaccine Strategy for Women of Reproductive Age (20162017) . Iran J Med Microbiol. 2019; 12 (5) :357-362 


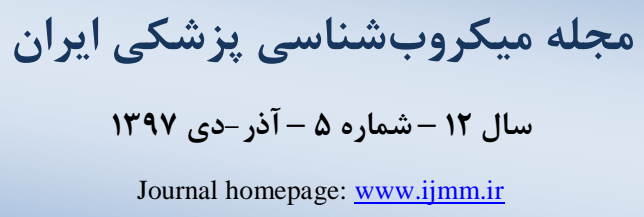

\section{شيوع سرمى IgG ضدويروس واريسلا زوستر در دانشجويان دانشكاه علوم يزشكى بابل: اهميت

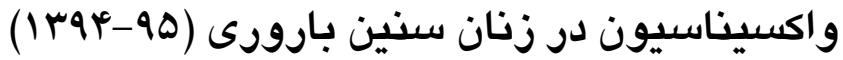

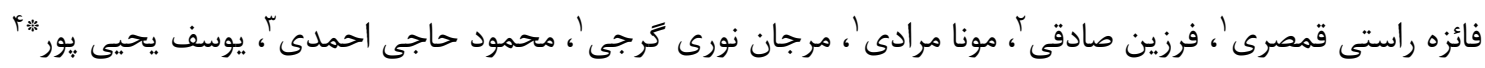

1- - كميتهُ تحقيقات دانشجويى، دانشكاه علوم يزشكى بابل، بابل، ايران

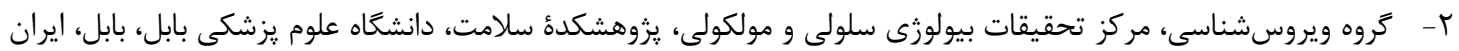

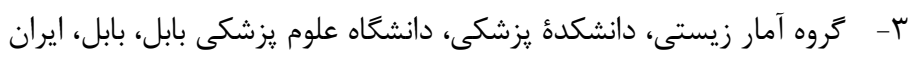

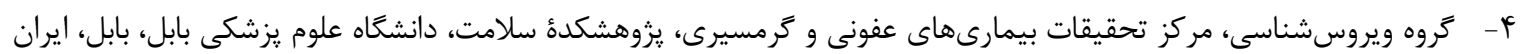

\section{جكيده}

زمينه و هدف: آبلهمرغان بيمارى بسيار مسرى است كه عامل آن ويروس واريسلا زوستر (Varicella Zoster Virus;

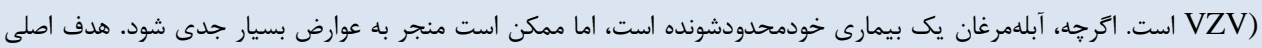

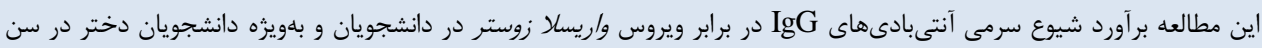
قبل از ازدواج، در دانشخاه علوم يزشكى بابل است.

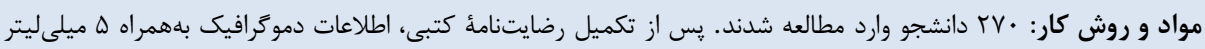

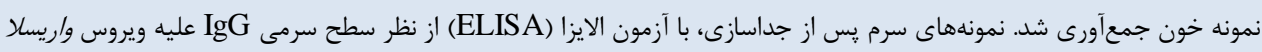
زوستر بررسى شدند.

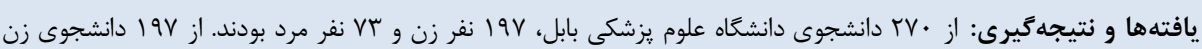

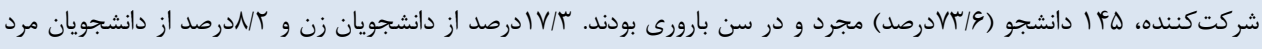

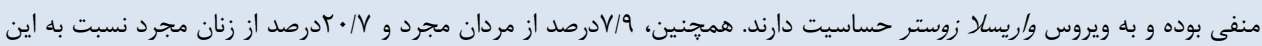

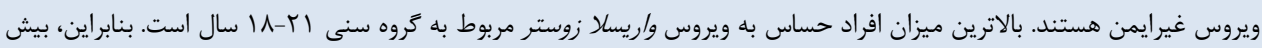

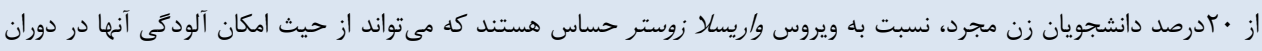

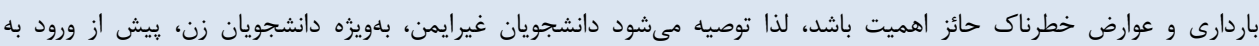
بخشهاى بالينى واكسينه شوند. كلمات كليدى: آبلهمرغان، ويروس واريسلا زوستر، VZV IgG، واكسيناسيون

كبيرايت (): حق جاب، نشر و استفادهُ علمى از اين مقاله براى مجلؤ ميكروبشناسى بزشكى ايران محفوظ است.

\section{اطلاعات مقاله}

تاريخهُهُ مقاله

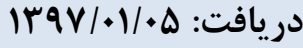

يذيرش:q

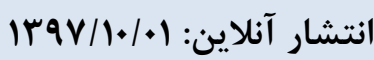

موضوع:

ويروس شناسى يزشكى

IJMM1397;12(5): 357-362

نويسندهُ مسئول:

يوسف يحيى ثيور

دانشيار، گروه ويروسشناسى، مركز

تحقيقات بيمارىهاى عفونى و كرمسيرى، يزوهشكدة سلامت، دانشعاه علوم يزشكى بابل، بابل، ايران

بست الكترونيك: uyahyapoor@yahoo.com
از طريق غشاهاى مخاطى دستعاه تنفسى يا بافت ملتحمه جشم

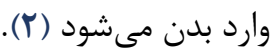

اگرجه، آبلهمرغان يك بيمارى خفيف و خودمحدودشونده

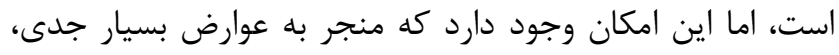
حتى مرگ افراد بزرگسال، زنان باردار و بيماران با ضعف سيستم
ويروس واريسلا زوستر Varicella Zoster Virus; VZV) متعلق به زيرخانواده آلفاهريس ويروس و عامل بيمارى آبلهمرغان است. ويروس واريسلا زوستر يس از آلودگى، در سلولهاى عصبى بـى (نرون) مخفى شده و با عود مجدد، موجب هريس زوستر (بيمارى روى رونى

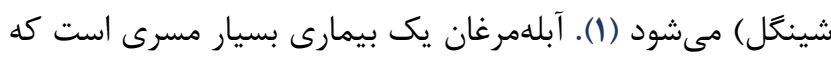




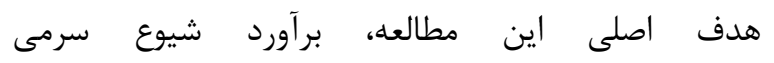
آنتىبادى اين IgG در برابر ويروس واريسلا دئل زوستر در جوانان دانشجو و بهويزه دانشجويان دختر در سن يِيش از ازدواج در دانشعاه علوم يزشكى بابل است.

\section{مواد و روش هات دران}

rV. اين مطالعهُ مقطعى - توصيفى با شركت داوطلبانه

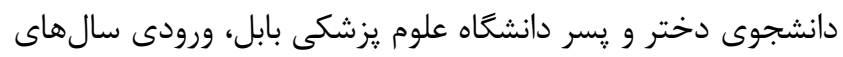

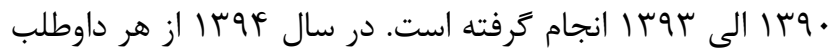
يس از تكميل رضايتنامهٔ كتبى و جكىليستى حاوى اطلاعات

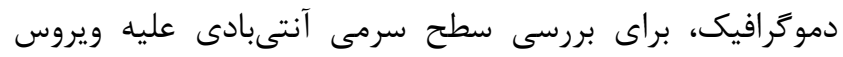

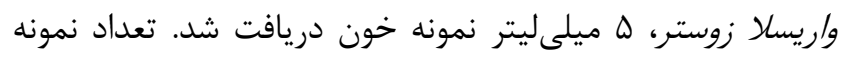
براساس سرشمارى و با مشاركت داوطلبانهٔ دانشجويان براساس دراس فراخوان عمومى بوده است و دانشجويانى كه در زمان نمونهَيرى

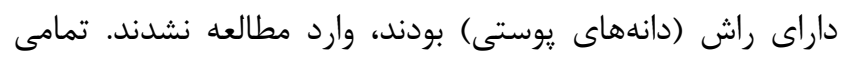
نمونهها از نظر سطح سرمى IgG عليه ويروس واريسلا زوستر با لإنا كيت تجارى الايزا NovaLisa (ساخت شركت NovaTec كشور

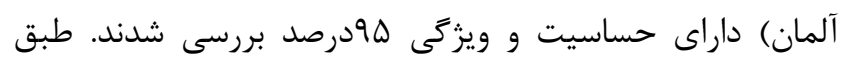

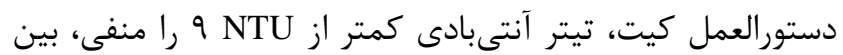

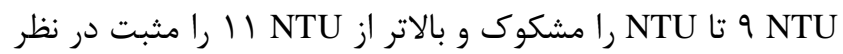

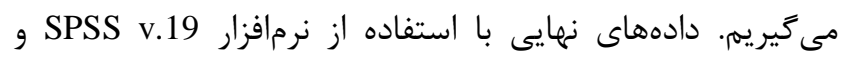
آزمونهاى آمارى مجذور كاى و

\section{يافته ها و بحث}

در اين مطالعه، از بين • PV دانشجوى دانشكاه علوم يزشكى

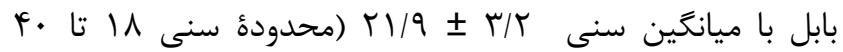

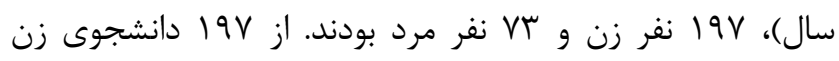

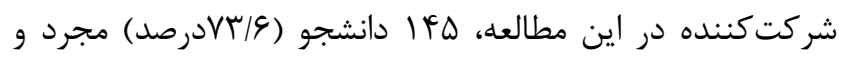

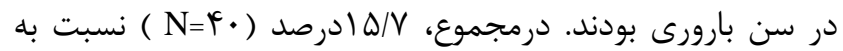
ويروس واريسلا زوستر غيرايمن يا حساس بودند. در حالى كه

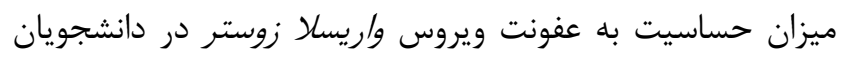
دانشخاه يزشكى Hacettepe در كشور تركيه (همسائ غربى ايران) بهمور جشمغيرى كمتر تزارش شده است (9). اين مطالعه روى

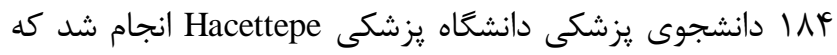

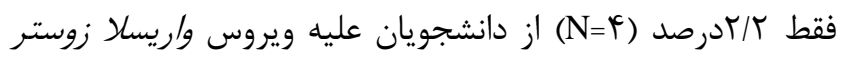

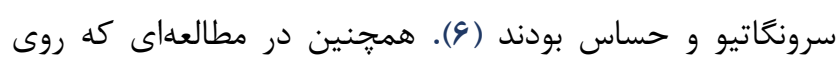

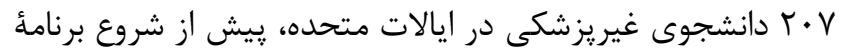
واكسيناسيون عليه ويروس واريسلا زوستر انجام كرفت، ب//كرصد از دانشجويان عليه ويروس واريسلا زوستر سرونغاتيو بودند (V).
ايمنى شود (1). عفونت اوليه ويروس واريسلا زوستر در زنان باردار

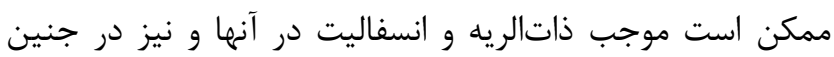
شود. عفونت مادرزادى آبلهمرغان در ماههاى اول باردارى ممكن التهن است بهعنوان سندرم آبلهمرغان مادرزادى Congenital Varicella) دyndrome)

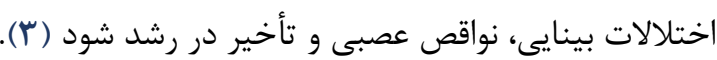
عفونت ويروس واريسلا زوستر، طى سهماهئ سوم باردارى يا نزديك به زايمان مىتواند موجب عفونت در نوزاد شود و درنتيجه ممكن است منجر به افزايش ميزان مركَومير اطفال تا • بادرصد

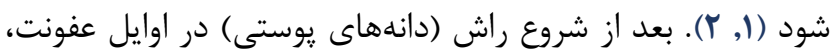
آنتىبادى ضدويروس واريسلا زوستر توليد مىشود و براى سال الها

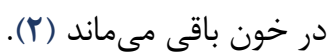
با وجود استفاده عمومى از واكسن آبلهمرغان آنان در دوران

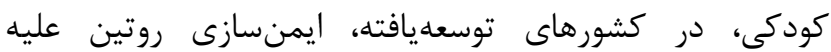
آبلهمرغان در كشورهاى در حال توسعه از جمله ايران انجام

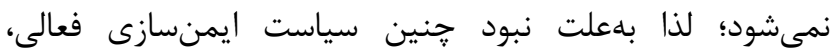
جمعيت آسيب پيذير جامعه نظير زنان كروه سنى قبل از ازدواج، در معرض خطر بيشرفت عفونت هستند.

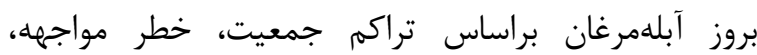

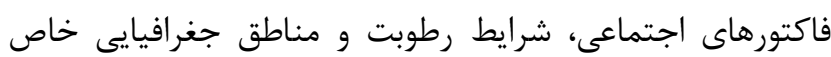
دنيا متفاوت است (1). إيدميولوزى عفونت ويروس واريسلا زوستر در نواحى گرمسيرى، جايى كه بخش نسبتا زيادى از افراد

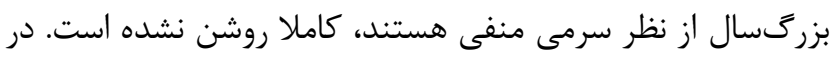

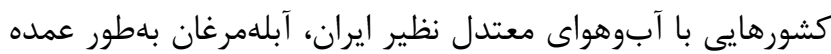

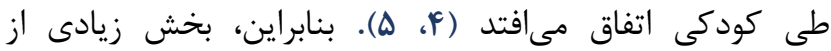

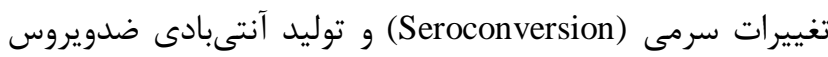

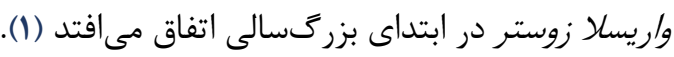
در ايران، سطح ايمنى نسبت به ويروس واريسلا زوستر از

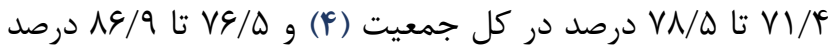

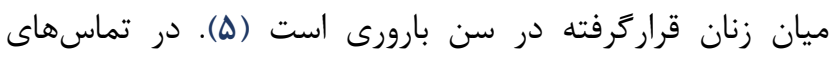

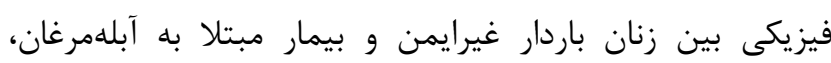

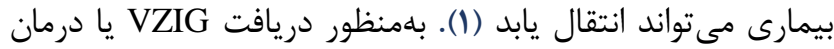
ضدويروسى (Antiviral)، زنان باردار بايد ازنظر وضعيت ايمنىشان

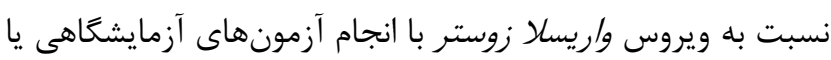

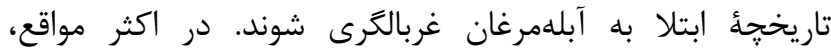

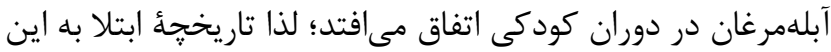
بيمارى كاملا مشخص نيست. 
مداخلاتى براى تهيه و انجام واكسيناسيون ويروس واريسلا زوستر در اين جمعيت هستند.

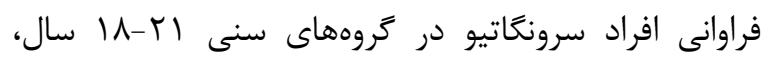

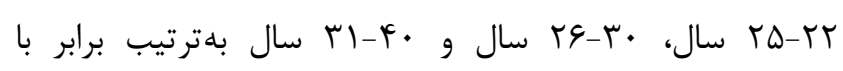

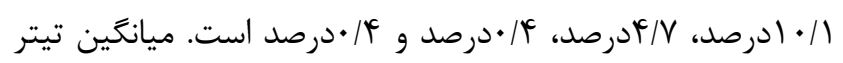

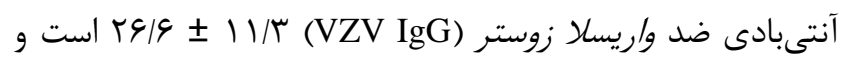

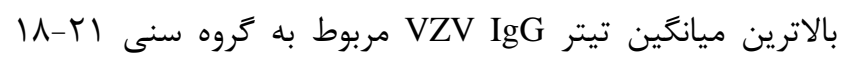

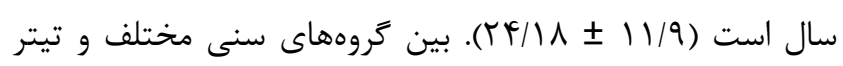

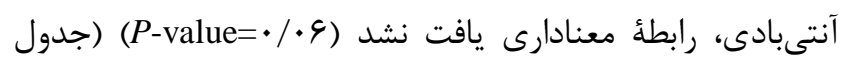

شماره ().

در اين مطالعه، ميزان شيوع آنتىبادى عليه ويروس واريسلا

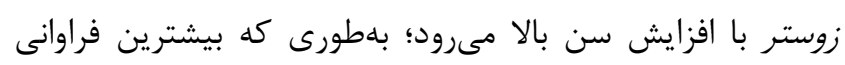

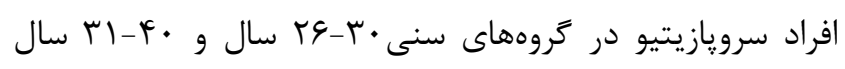

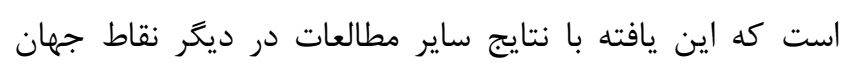

$$
\text { همخوانى دارد (rا-•(1). }
$$

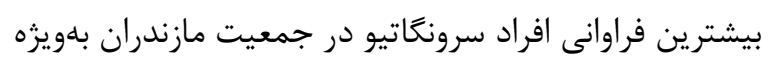

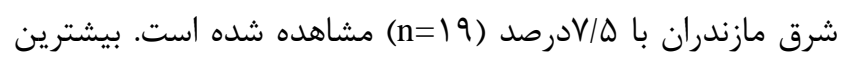

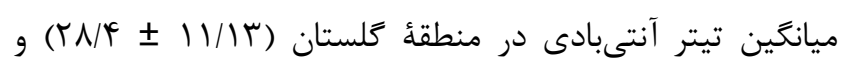

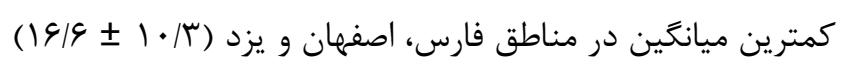

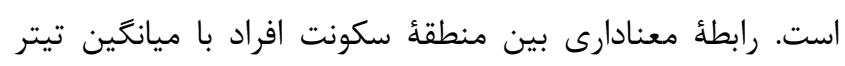

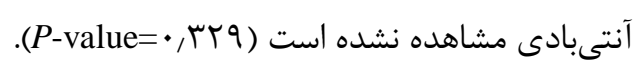

يكى از محدوديتهاى اين مطالعه، نامتقارنى بين حجم

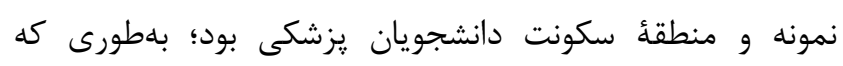

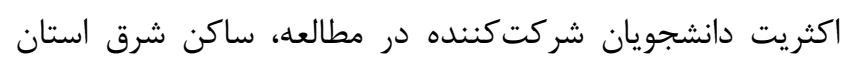

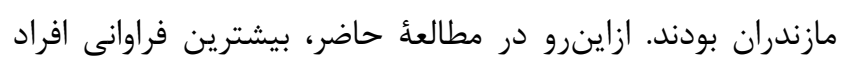

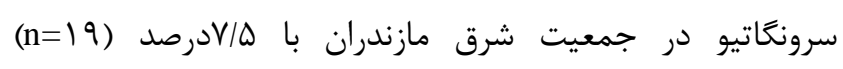
مشاهده شد.

در اين مطالعهُ مقطعى، دانشجويان يزشكى (بهويزه

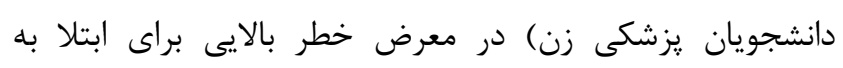

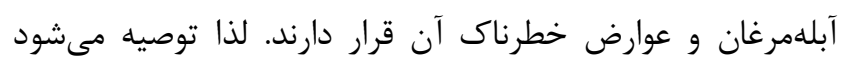

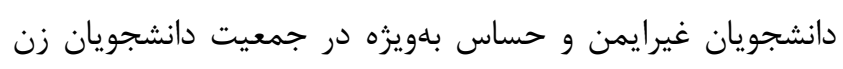

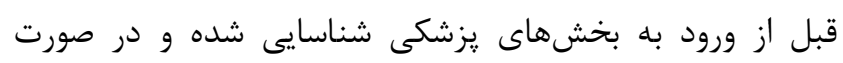

$$
\text { امكان واكسينه شوند. }
$$

شيوع بالاى دانشجويان يزشكى حساس و غيرايمن عليه ويروس

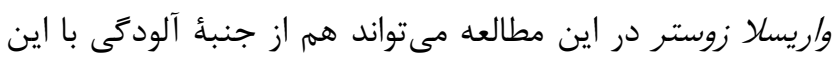

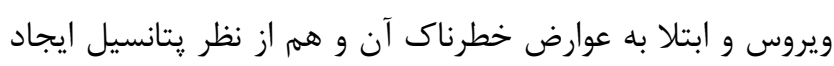

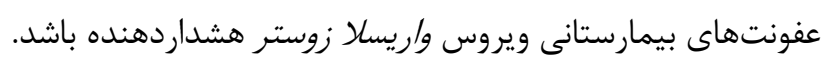
آزمون الايزا براى سنجش سطح سرمى آنتىبادى عليه

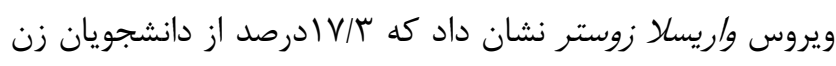
(N=34)

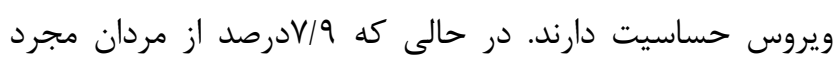
و (N=Q) واريسلا زوستر غيرايمن هستند.

از 19V دانشجوى زن شركت كننده در اين مطالعه،

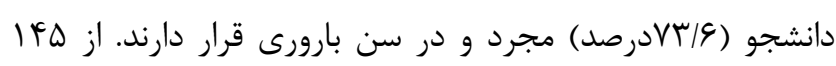

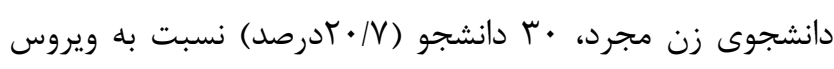

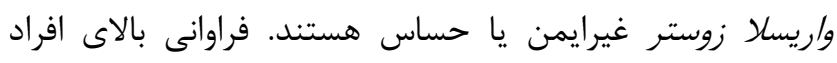

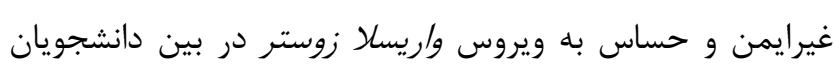

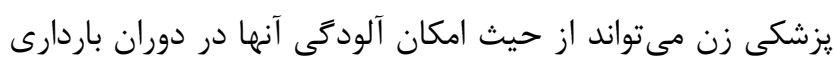

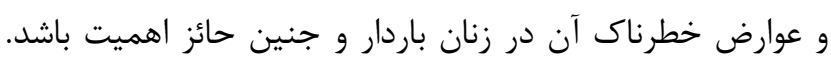

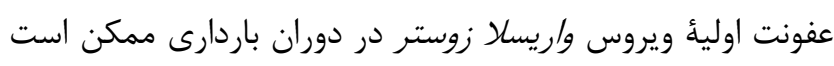

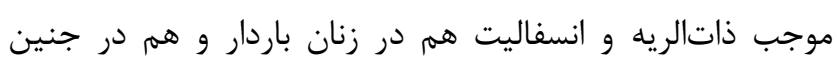

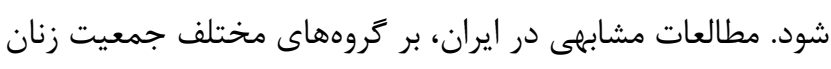

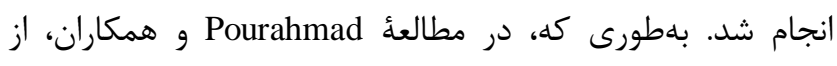

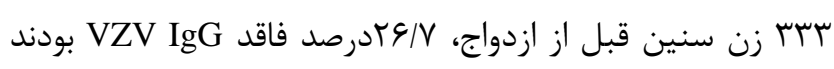

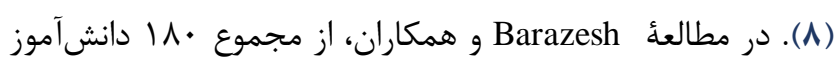

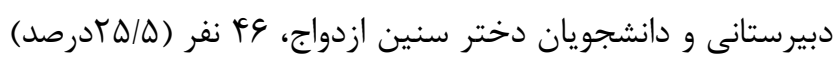

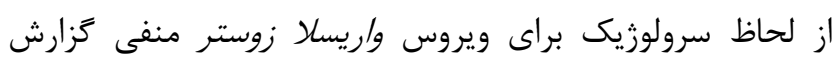

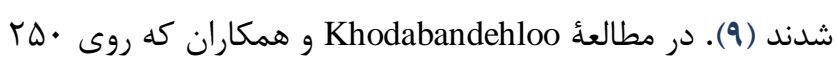

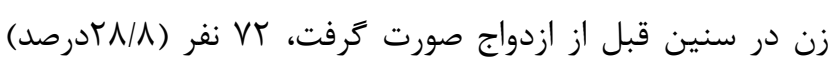

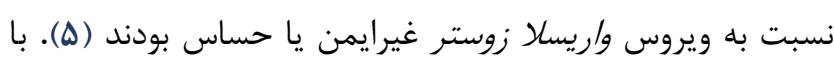

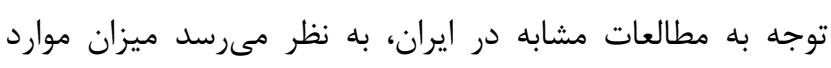

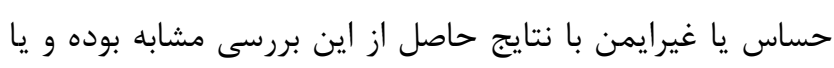

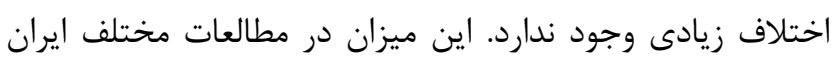

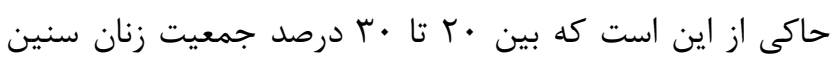

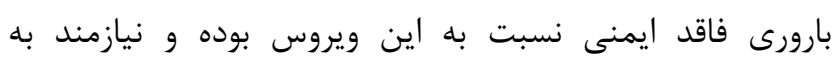




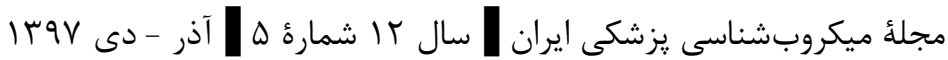

جدول ا. تيتر آنتى بادى VZV IgG در دانشجويان براساس وضعيت ازدواج

\begin{tabular}{|c|c|c|c|c|c|}
\hline درصد & تعداد & ميانغين & نتيجة آزمون NTU & وضعيت ازدواج & جنس \\
\hline$T r / D$ & $\Delta \Lambda$ & $r \Lambda / \cdot V$ & ايمنى & \multirow{3}{*}{ مجرد } & \multirow{6}{*}{ مرد } \\
\hline $1 / 9$ & $\Delta$ & F/VI & حساس & & \\
\hline$T Y / F$ & \& & $r \varepsilon / T \mid$ & كل & & \\
\hline$\Gamma / \Delta$ & 9 & $r F / 1 \Lambda$ & ايمنى & \multirow{3}{*}{ متأهل } & \\
\hline f & 1 & $\Gamma / \Delta \varphi$ & حساس & & \\
\hline$r / q$ & $1 \cdot$ & $r Y / I I$ & جمع & & \\
\hline fr/A & $11 \pi$ & tV/IS & ايمنى & \multirow{4}{*}{ مجرد } & \multirow{7}{*}{ 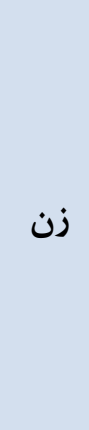 } \\
\hline $11 / 9$ & $r$. & $\mathrm{F} / \mathrm{\Lambda \Lambda}$ & حساس & & \\
\hline$\cdot \mid \Lambda$ & r & $1 \cdot 1 \cdot 0$ & حد وسط & & \\
\hline$\Delta G / T$ & $1 F \Delta$ & $r Y / M I$ & كل ل & & \\
\hline If & rq & r\&/AD & ايمنى & \multirow{3}{*}{ متأهل } & \\
\hline $1 / 9$ & r & $\varepsilon / T$. & حساس & & \\
\hline $10 / 9$ & f. & TF/VA & كل & & \\
\hline
\end{tabular}

كروه ميكروبشناسى و بهويزه تمامى دانشجويان گَرامى دانشكاه

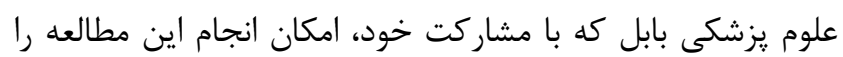

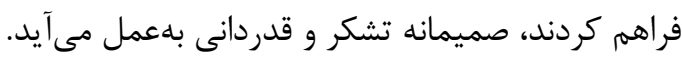

$$
\text { تعارض منافع }
$$

بين نويسندكان تعارض در منافع كزارش نشده است.

اين يزوهش با حمايت مالى معاونت محترم تحقيقات و

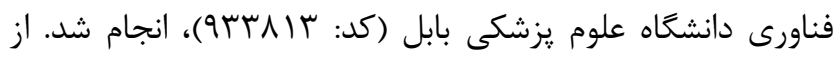

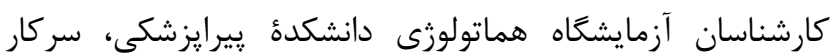
خانم فرحناز صديقيان و خديجه ركابيور، همكاران و كارشناسان إنانيان

\section{References}

1. Arvin AM. Varicella-zoster virus. Clinical Microbiology Reviews. 1996; 9(3): 361-81. https://doi.org/10.1128/CMR.9.3.361

2. Arvin AM. Humoral and cellular immunity to varicella-zoster virus: an overview. J Infect Dis. 2008; 197 ( 2): S58-60.

3. Arvin AM, Moffat JF, Redman R. Varicella-zoster virus: aspects of pathogenesis and host response to natural infection and varicella vaccine. Adv Virus Res. 1996; 46: 263-309. https://doi.org/10.1016/S0065-3527(08)60074-3

4. Amjadi O, Rafiei A, Haghshenas MR, Alizadeh Navaei R, Valadan R, Hosseini-Khah, et al. A systematic review and meta-analysis of seroprevalence of varicella zoster virus :A nationwide population-based study. Journal of Clinical Virology. 2017; 87: 49-59. https://doi.org/10.1016/j.jcv.2016.12.001

5. Majidy P, Khodabandehloo M, Azadi NA. Seroprevalence of Varicella zoster virus antibody among young women before marriage in Sanandaj, Iran. Iranian Journal of Microbiology. 2016; 8(2): 147-52.

6. Kanra G, Yalçın S, Kara A, Yurdakok K, Pehlivanli T. Varicella seroprevalence among Turkish medical students and the validity of disease history. Infect Control Hosp Epidemiol. 2003; 24(11): 795-6. https://doi.org/10.1086/502910

7. Mahamud A, Leung J, Masunu-Faleafaga Y, Teshale E, Williams R, Dulski T, et al. Varicella zoster virus in American Samoa: seroprevalence and predictive value of varicella disease history in elementary and college students. Epidemiol Infect. 2014; 142(5): 1002-7. https://doi.org/10.1017/S095026881300174X 
8. Pourahmad M, Davami MH, Jahromi AR. Evaluation of anti-varicella antibody in young women before their marriage: A sero-epidemiologic study in Iran. Journal of Clinical Virology. 2010; 48(4):

260-3.

https://doi.org/10.1016/j.jcv.2010.04.015

9. Barazesh A, Zandi K, Hadavand F, Moatamed N, Hefzollah F, Hefzollah b, et al. Seroepidemiology of Rubella, Cytomegalovirus, Herpes simplex \& Varicella zoster virus in college women of Bushehr. Iran South Med J. 2014; 16(6): 459-66.

10. Wiese-Posselt M, Siedler A, Mankertz A, Sauerbrei A, Hengel H, Wichmann O, et al. Varicella-zoster virus seroprevalence in children and adolescents in the pre-varicella vaccine era, Germany. BMC Infect Dis. 2017; 17(1): 356. https://doi.org/10.1186/s12879-017-2461-2

11. Kose S, Mandiracioglu A, Serin Senger S, Ulu Y, Cavdar G, Gol B, et al. Seroprevalence of varicellazoster virus in the prevaccine era: a populationbased study in Izmir, Turkey. J Infect Public Health. 2013; 6(2): 115-9 https://doi.org/10.1016/j.jiph.2012.10.003

12. Lin MR, Kuo CC, Hsieh Yc, Huang YL, Huang YC, Hung YT, et al. Seroepidemiology of varicella among elementary school children in northern Taiwan. J Microbiol Immunol Infect. 2017; 50(3): 321-6. https://doi.org/10.1016/j.jmii.2015.07.007 